\title{
PENGARUH WAKTU PENGELASAN TITIK (SPOT WELDING) TERHADAP KEKERASAN, KEKUATAN GESER DAN DIAMETER NUGGET PADA BAJA SPCEN $1,6 \mathrm{~mm}$
}

\author{
Riantono Rasyid ${ }^{1}$, Novi Sukma Drastiawati ${ }^{2}$ \\ 1,2 Jurusan Teknik Mesin, Fakultas Teknik, Universitas Negeri Surabaya \\ ${ }^{1}$ riantonorasyidemhs. unesa.ac.id, 2novidrastiawati@unesa.ac.id
}

\begin{abstract}
Abstrak - Perkembangan teknologi di bidang manufaktur saat ini sangat pesat. Salah satu dari proses yang penting di dalamnya adalah penyambungan (joining), diantaranya proses tahanan pengelasan titik (resistance spot welding) atau yang lebih dikenal sebagai pengelasan titik (spot welding). Penggunaan las titik memiliki beberapa keunggulan antara lain bentuk sambungan rapi, prosesnya lebih cepat, sambungan lebih rapat dan pengoperasiannya relatif mudah serta tidak memerlukan logam pengisi (filler). Penyambungan bahan baja berbentuk plat yang relatif tipis dengan memakai tahanan pengelasan titik (resistance spot welding) merupakan salah satu alternatif pilihan yang banyak digunakan oleh industri produksi parts otomotif. Namun demikian belum terdapat data mengenai waktu yang terbaik dan data mengenai uji kekerasan, besar diameter nugget, dan uji geser pada material baja SPCEN. Penelitian ini bertujuan untuk mengetahui pengaruh waktu pengelasan titik (spot welding) terhadap kekerasan, kekuatan geser dan besar diameter nugget pada material baja SPCEN. Penelitian ini menggunakan metode eksperimen dengan variable waktu 1 detik, 2 detik dan 3 detik dengan standart material SPCEN JIS G 3141, standart pengujian kekerasan menggunakan DIN 50103 dan standart pengujian geser menggunakan ASTM D 1002. Hasil penelitian pada diameter nugget tiap waktu memiliki ukuran nugget yang sama besar yaitu $3,3 \mathrm{~mm}$. Hasil rata-rata kekerasan nugget terendah terdapat pada pelat baja yang ditandai dengan nama ABC waktu 1 detik dengan rata-rata kekerasan nugget 116,6 HRB dan rata-rata kekerasan nugget tertinggi terdapat pada baja GHI waktu 3 detik dengan rata-rata kekerasan nugget 117,9 HRB. Hasil rata-rata kekuatan geser terendah terdapat pada baja ABC waktu 1 detik dengan kekuatan geser tegangan maksimal 294,82 N/m² dan beban maksimal 1592,01 Newton, hasil rata-rata kekuatan geser tertinggi terdapat pada pelat baja yang ditandai dengan nama GHI waktu 3 detik dengan tegangan maksimal 415,89 N/m² dan beban maksimal 2245,83 Newton. Dengan demikian semakin lama waktu pengelasan titik (spot welding) maka semakin besar arus yang digunakan, semakin besar pula panas yang ditimbulkan dan menjadikan kekerasan dan kekuatan geser semakin kuat. Menunjukkan waktu yang terbaik pada pengelasan titik (spot welding) plat baja SPCEN 1,6 mm dengan waktu 3 detik.
\end{abstract}

Kata Kunci_- pengelasan titik; waktu pengelasan titik; kekerasan; kekuatan geser; diameter nugget; baja SPCEN.

Abstract - The development of technology in manufacturing is currently very fast. One of the important processes involved is joining, including the process of resistance spot welding or better known as spot welding. The use of point welding has several advantages, including a neat shape of the joint, the process is faster, the connection is tighter and the operation is relatively easy and does not require filler metal. The connection of relatively thin plate-shaped steel using resistance spot welding is an alternative option that is widely used by the automotive parts production industry. However, there are no data regarding the best time and data regarding the hardness test, nugget diameter, and shear test on SPCEN steel material. This study aims to determine the effect of spot welding time on hardness, shear strength and nugget diameter on SPCEN steel material. This study used an experimental method with a time variable of 1 second, 2 seconds and 3 seconds with standard material SPCEN JIS G 3141, standard hardness testing using DIN 50103 and standard shear testing using ASTM D 1002. equal that is $3.3 \mathrm{~mm}$. The lowest average nugget hardness results are found on steel plates marked with the name ABC, time of 1 second with an average nugget hardness of 116.6 $H R B$ and the highest average nugget hardness is found on GHI steel within 3 seconds with an average nugget hardness of 117,9 HRB. The lowest average yield of shear strength is found in ABC steel at 1 second with a maximum shear strength of $294.82 \mathrm{~N} / \mathrm{m}^{2}$ and a maximum load of 1592.01 Newton, the highest average yield of shear strength is found on steel plates marked with the name GHI time 3 seconds with a maximum tension of $415.89 \mathrm{~N} / \mathrm{m}^{2}$ and a maximum load of 2245.83 Newton. Thus the longer the spot welding time (spot welding), the greater the current used, the greater the heat generated and the hardness and shear strength become stronger. Shows the best time for spot welding (spot welding) of $1.6 \mathrm{~mm}$ SPCEN steel plate in 3 seconds.

Keywords — spot welding; spot welding time; hardness; shear; nugget diameter; SPCEN steel. 


\section{PENDAHULUAN}

Berbagai pekerjaan yang terkait dengan pemanfaatan tenaga listrik semakin berkembang pesat, salah satunya adalah pengelasan. Banyak perusahaan jasa pengelasan yang saat ini sedang berkembang di Indonesia. Pengelasan merupakan cara penyambungan logam yang paling banyak digunakan karena pengelasan mempunyai kelebihan diantaranya adalah hasil sambungannya lebih kuat, murah, dan efisien. Pengelasan yang digunakan bermacam-macam, mulai dari pengelasan manual hingga pengelasan yang menggunakan teknologi robot. Salah satu metode atau proses pengelasan yang populer digunakan dalam industri produksi adalah pengelasan titik (Drastiawati et. al).

RSW (Resistance Spot Welding) adalah salah satu metode penyambungan logam dengan pengelasan pada permukaan yang memanfaatkan arus listrik dengan dua buah plat yang disambung sehingga permukaan tersebut menjadi panas dan mencair karena adanya resistansi listrik. Pengelasan titik banyak digunakan di industri besar seperti industri mobil dan industri motor (Wiryosumarto dan Okumura, 1996).

Proses pengerjaan las ini lebih cepat dan lebih rapi hasilnya dibandingkan dengan menggunakan las asetelin dan las busur listrik karena las yang dihasilkan tidak mengandung terak las. Penggunaan las titik memiliki beberapa keunggulan antara lain bentuk sambungan rapi, prosesnya lebih cepat, sambungan lebih rapat dan pengoperasiannya relatif mudah serta tidak memerlukan logam pengisi (filler).

Pada pengelasan titik, lama penekanan pada waktu proses pengerjaan akan menentukan hasil las serta kekuatan las yang diinginkan. Waktu sangat diperlukan untuk mengoptimalkan dan menghasilkan produktifitas kerja, karena menjadi hal yang penting untuk tuntutan hasil yang tinggi.

Dalam penerapan las titik, masih ada beberapa perusahaan yang belum memiliki data uji kekerasan dan uji kekuatan geser berdasarkan perubahan waktu pengelasan pada material yang digunakan untuk baja SPCEN. Baja SPCEN (Steel Plate Cold Elongation Non-Ageing) tergolong baja karbon rendah yang didefinisikan sebagai baja canai dingin digulung dengan kualitas (cold rolled steel sheet with deep drawing quality). Baja SPCEN dalam (JIS) Japan Industrial Standard mempunyai kode seperti SPCC (Steel Plate Cold Common) : JIS G 3141 .

Pada penelitian ini, baja yang digunakan SPCEN (JIS G 3141) untuk tempat sensor bahan bakar (fuel tank) pada mesin motor suzuki satria FU 150 tahun 2012. Timbul suatu pemikiran untuk menentukan waktu pengelasan yang optimal agar dapat mengetahui kekerasan, kekuatan geser dan diameter nugget pada sambungan baja karbon rendah SPCEN (JIS G 3141 : 2005).

\section{METODE}

Penelitian ini menggunakan jenis penelitian eksperimen (experimental research) yang bertujuan untuk mengetahui kekerasan, kekuatan geser dan besar diameter nugget yang dihasilkan pada baja SPCEN dengan variabel waktu. Menggunakan material baja SPCEN JIS G 3141 dengan ukuran baja standart ASTM D 1002. Pengujian kekerasan menggunakan HRB dengan standart DIN 50103 dan pengujian geser menggunakan alat UTM dengan standart ASTM D 1002.

\section{Variabel Penelitian}

- Variabel bebas dalam penelitian ini adalah waktu 1 detik, 2 detik, 3 detik pada pengelasan titik (spot welding).

- Variabel terikat dalam penelitian ini adalah hasil pengelasan titik (spot welding) dengan tipe sambungan lap joint untuk kekerasan, kekuatan geser dan diameter nugget pada baja SPCEN.

- Variabel kontrol dalam operator pengelasan mesin las titik ini menggunakan tegangan arus 1,79 Volt.

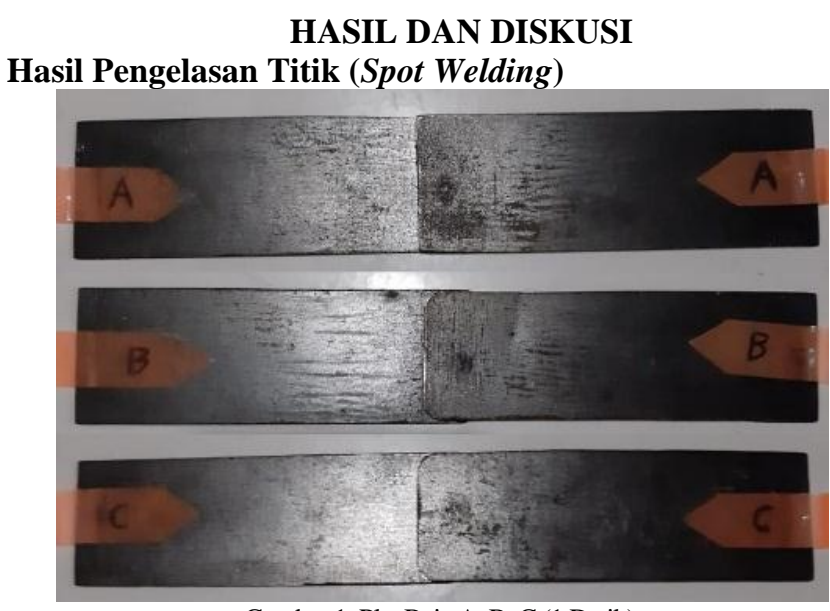

Gambar 1. Plat Baja A, B, C (1 Detik)

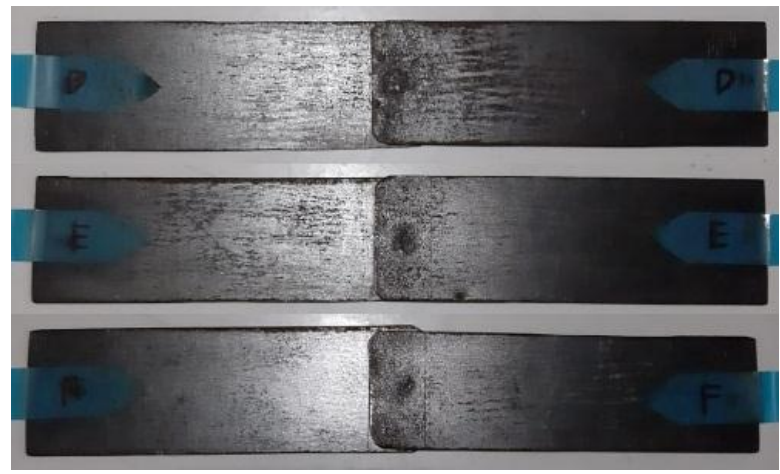

Gambar 2. Plat Baja D, E, F (2 Detik)

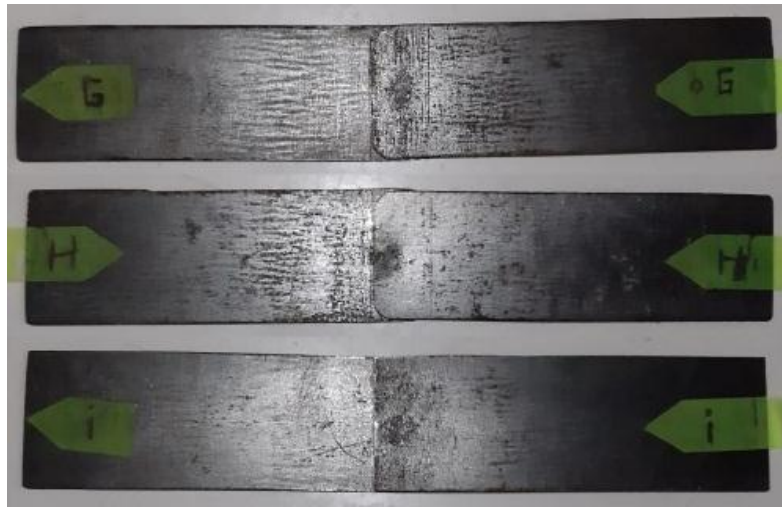

Gambar 3. Plat Baja G, H, I (3 Detik) 
Tabel I Hasil Pengukuran Diameter Nugget

\begin{tabular}{|c|c|c|c|}
\hline $\begin{array}{c}\text { Waktu } \\
\text { Pengelasan } \\
\text { (detik) }\end{array}$ & Spesimen & $\begin{array}{c}\text { Diameter } \\
\text { nugget }(\mathrm{mm})\end{array}$ & $\overline{\mathrm{X}}$ (Rata-rata) \\
\hline \multirow{3}{*}{1} & A & 3 & \multirow{3}{*}{$3,3 \mathrm{~mm}$} \\
\hline & B & 3,2 & \\
\hline & $\mathrm{C}$ & 3,6 & \\
\hline \multirow{3}{*}{2} & $\mathrm{D}$ & 3,5 & \multirow{3}{*}{$3,3 \mathrm{~mm}$} \\
\hline & $\mathrm{E}$ & 3,1 & \\
\hline & $\mathrm{F}$ & 3,3 & \\
\hline \multirow{3}{*}{3} & $\bar{G}$ & 3,4 & \multirow{3}{*}{$3,3 \mathrm{~mm}$} \\
\hline & $\mathrm{H}$ & 3,5 & \\
\hline & I & 3 & \\
\hline
\end{tabular}

Dari tabel I dapat diketahui bahwa terdapat perbedaan rata-rata diameter nugget tiap spesimen berdasarkan waktu pengelasan titik (spot welding) pada pelat baja SPCEN. Hasil pengelasan titik (spot welding) dengan waktu 1 detik, 2 detik dan 3 detik memiliki besar diameter nugget yang sama dengan rata-rata sebesar $3,3 \mathrm{~mm}$.

\section{Hasil Uji Kekerasan}

\begin{tabular}{|c|c|c|c|c|c|}
\hline \multirow[b]{3}{*}{$\begin{array}{c}\text { Waktu } \\
\text { Pengel } \\
\text { asan } \\
\text { (detik) }\end{array}$} & \multirow[b]{3}{*}{$\begin{array}{c}\text { Nama } \\
\text { Spesi } \\
\text { men }\end{array}$} & \multicolumn{4}{|c|}{ abel II Hasil Pengujian HRB } \\
\hline & & & Hasil & \multicolumn{2}{|c|}{$\bar{X}$ (Rata-rata) } \\
\hline & & $\begin{array}{c}\text { Titik } \\
\text { Kekera } \\
\text { san }\end{array}$ & $\begin{array}{c}\text { Titik } \\
\text { Kekera } \\
\text { san } \\
(\text { HRB })\end{array}$ & $\begin{array}{c}\overline{\mathrm{X}} \\
\text { nugget } \\
\mathrm{a}\end{array}$ & $\begin{array}{c}\bar{X} \\
\text { HAZ } \\
\text { b1 dan } \\
\text { b2 = b3 }\end{array}$ \\
\hline \multirow{10}{*}{1} & \multirow{3}{*}{ A } & $\mathrm{a}$ & 116,3 & 116,3 & - \\
\hline & & b1 & 118,3 & - & 118,2 \\
\hline & & b2 & 118,1 & & \\
\hline & \multirow{3}{*}{ B } & a & 116,7 & 116,7 & - \\
\hline & & b1 & 118,4 & \multirow{2}{*}{ - } & \multirow{2}{*}{118,3} \\
\hline & & b2 & 118,2 & & \\
\hline & \multirow{3}{*}{$\mathrm{C}$} & $\mathrm{a}$ & 116,9 & 116,9 & - \\
\hline & & b1 & 118,2 & \multirow{2}{*}{ - } & \multirow{2}{*}{118,1} \\
\hline & & b2 & 118,0 & & \\
\hline & \multicolumn{3}{|c|}{ Rata-rata total } & 116,6 & 118,2 \\
\hline
\end{tabular}

\begin{tabular}{|c|c|c|c|c|c|}
\hline \multirow[b]{2}{*}{$\begin{array}{l}\text { Waktu } \\
\text { Pengel } \\
\text { asan } \\
\text { (detik) }\end{array}$} & \multirow[b]{2}{*}{$\begin{array}{c}\text { Nama } \\
\text { Spesi } \\
\text { men }\end{array}$} & \multirow[b]{2}{*}{$\begin{array}{c}\text { Uji } \\
\text { Titik } \\
\text { Kekera } \\
\text { san }\end{array}$} & \multirow{2}{*}{$\begin{array}{c}\text { Hasil } \\
\text { Uji } \\
\text { Titik } \\
\text { Kekera } \\
\text { san } \\
\text { (HRB) }\end{array}$} & \multicolumn{2}{|c|}{$\overline{\mathrm{X}}$ (Rata-rata) } \\
\hline & & & & $\begin{array}{c}\overline{\mathrm{X}} \\
\text { nugget } \\
\mathrm{a}\end{array}$ & $\begin{array}{c}\overline{\mathrm{X}} \\
\text { HAZ } \\
\text { b1 dan } \\
\text { b2 = b3 }\end{array}$ \\
\hline \multirow{10}{*}{2} & \multirow{3}{*}{$\mathrm{D}$} & $\mathrm{a}$ & 117,2 & 117,2 & - \\
\hline & & b1 & 118,1 & \multirow{2}{*}{ - } & \multirow{2}{*}{118,2} \\
\hline & & b2 & 118,3 & & \\
\hline & \multirow{3}{*}{$\mathrm{E}$} & $\mathrm{a}$ & 117,2 & 117,2 & - \\
\hline & & b1 & 118,2 & \multirow{2}{*}{-} & \multirow{2}{*}{118,3} \\
\hline & & b2 & 118,4 & & \\
\hline & \multirow{3}{*}{ F } & $\mathrm{a}$ & 116,8 & 116,8 & - \\
\hline & & b1 & 118,5 & \multirow{2}{*}{ - } & \multirow{2}{*}{118,6} \\
\hline & & b2 & 118,6 & & \\
\hline & \multicolumn{3}{|c|}{ Rata-rata total } & 117,1 & 118,4 \\
\hline \multirow{10}{*}{3} & \multirow{3}{*}{ G } & $\mathrm{a}$ & 117,8 & 117,8 & - \\
\hline & & b1 & 118,4 & \multirow{2}{*}{ - } & \multirow{2}{*}{118,5} \\
\hline & & $\mathrm{b} 2$ & 118,5 & & \\
\hline & \multirow{3}{*}{$\mathrm{H}$} & $\mathrm{a}$ & 117,6 & 117,6 & - \\
\hline & & b1 & 118,3 & - & 118,5 \\
\hline & & b2 & 118,7 & & \\
\hline & \multirow{3}{*}{ I } & $\mathrm{a}$ & 118,3 & 118,3 & - \\
\hline & & b1 & 119,3 & & \multirow{2}{*}{119,2} \\
\hline & & $\mathrm{b} 2$ & 119,1 & & \\
\hline & \multicolumn{3}{|c|}{ Rata-rata total } & 117,9 & 118,7 \\
\hline
\end{tabular}

Dari tabel II dapat diketahui bahwa terdapat perbedaan rata-rata titik uji kekerasan tiap spesimen berdasarkan waktu pengelasan titik (spot welding) pada pelat baja SPCEN. Hasil rata-rata total uji titik kekerasan dengan waktu 1 detik dititik nugget (a) sebesar 116,6 HRB dan HAZ (b3) sebesar 118,2 $\mathrm{HRB}$, sedangakan rata-rata total uji titik kekerasan dengan waktu 2 detik dititik nugget (a) sebesar 117,1 HRB dan HAZ (b3) sebesar 118,4 HRB dan rata-rata total uji titik kekerasan dengan waktu 3 detik dititik nugget (a) sebesar 117,9 HRB dan HAZ (b3) sebesar 118,7 HRB. 


\section{Hasil Uji Geser}

\begin{tabular}{|c|c|c|c|}
\hline \multirow[b]{2}{*}{$\begin{array}{c}\text { Waktu } \\
\text { Pengelasan } \\
\text { (detik) }\end{array}$} & \multirow[b]{2}{*}{ Spesimen } & \multicolumn{2}{|c|}{ Hasil Uji Geser } \\
\hline & & $\begin{array}{c}\boldsymbol{\tau} \\
\text { Tegangan } \\
\left(\mathrm{N} / \mathrm{m}^{2}\right)\end{array}$ & $\begin{array}{c}\mathrm{F} \\
\text { Beban } \\
\text { Maksimal } \\
\text { (Newton) }\end{array}$ \\
\hline \multirow{4}{*}{1} & A & 298,17 & 1610,14 \\
\hline & B & 292,19 & 1577,8 \\
\hline & $\mathrm{C}$ & 294,09 & 1588,09 \\
\hline & Rata-rata & 294,82 & 1592,01 \\
\hline \multirow{4}{*}{2} & $\mathrm{D}$ & 384,74 & 2077,6 \\
\hline & $\mathrm{E}$ & 410,24 & 2215,29 \\
\hline & $\mathrm{F}$ & 394,27 & 2129,05 \\
\hline & Rata-rata & 396,42 & 2140,65 \\
\hline \multirow{4}{*}{3} & $\mathrm{G}$ & 402,25 & 2172,17 \\
\hline & $\mathrm{H}$ & 434,19 & 2344,65 \\
\hline & I & 411,24 & 2220,68 \\
\hline & Rata-rata & 415,89 & 2245,83 \\
\hline
\end{tabular}

Dari tabel III dapat diketahui bahwa terdapat perbedaan rata-rata tegangan dan beban tiap spesimen berdasarkan waktu pengelasan titik (spot welding) pada pelat baja SPCEN. Hasil rata-rata pengujian geser dengan waktu 1 detik untuk stress (tegangan) sebesar 294,82 N/m² dan beban maksimal sebesar 1592,01 Newton, sedangkan pengujian geser dengan waktu 2 detik untuk stress (tegangan) sebesar 396,42 N/m² dan beban maksimal sebesar 2140,65 Newton dan pengujian geser dengan waktu 3 detik untuk stress (tegangan) sebesar $415,89 \mathrm{~N} / \mathrm{m}^{2}$ dan beban maksimal sebesar 2245,83 Newton.

\section{Hasil Data Uji Anova One Way Pengujian Kekerasan}

Tabel IV Uji Anova One Way Kekerasan ANOVA

\begin{tabular}{l|r|r|r|r|r|}
\hline Kekerasan & \multicolumn{1}{|c|}{ Sum of Squares } & df & Mean Square & F & Sig. \\
\hline Between Groups & 2,487 & 2 & 1,243 & 13,482 &, 006 \\
Within Groups &, 553 & 6 &, 092 & & \\
Total & 3,040 & 8 & & & \\
\hline
\end{tabular}

Pada tabel IV dapat disimpulkan bahwa nilai $\mathrm{F}$ hitung lebih besar daripada nilai $\mathrm{F}$ tabel $(13,482>5,14)$ dan nilai signifikan 0,006 kurang dari 0,05 $(0,00<0,05)$ maka Ha diterima dan Ho ditolak. Dengan kata lain ada pengaruh waktu pengelasan titik (spot welding) secara signifikan terhadap kekerasan pada plat baja SPCEN.
Tabel V Hasil Uji LSD Pengujian Kekerasan Multiple Comparisons

Dependent Variable: Kekerasan

LSD

\begin{tabular}{|c|c|c|c|c|c|c|}
\hline \multirow[b]{2}{*}{ (1) Waktu } & \multirow[b]{2}{*}{ (J) Waktu } & \multirow{2}{*}{$\begin{array}{c}\text { Mean } \\
\text { Difference (1-J) }\end{array}$} & \multirow[b]{2}{*}{ Std. Error } & \multirow[b]{2}{*}{ Sig. } & \multicolumn{2}{|c|}{$95 \%$ Confidence Interval } \\
\hline & & & & & Lower Bound & Upper Bound \\
\hline \multirow[t]{2}{*}{1 Detik } & 2 Detik & -.43333 & 24795 & .131 & $-1,0401$ & .1734 \\
\hline & 3 Detik & $-1,26667^{\circ}$ & .24795 & .002 & $-1,8734$ &,- 6599 \\
\hline \multirow[t]{2}{*}{2 Detik } & 1 Detik & .43333 & ,24795 & 131 & -.1734 & 1,0401 \\
\hline & 3 Detik & $-.83333^{*}$ & ,24795 & .015 & $-1,4401$ &,- 2266 \\
\hline \multirow[t]{2}{*}{3 Detik } & 1 Detik & $1,26667^{*}$ & ,24795 &, 002 & .6599 & 1,8734 \\
\hline & 2 Detik & $.83333^{*}$ &, 24795 & .015 & .2266 & 1,4401 \\
\hline
\end{tabular}

${ }^{*}$. The mean difference is significant at the 0.05 level.

Pada tabel V dapat diketahui 1 detik dengan 2 detik atau sebaliknya nilai signifikannya 0,131 bahwa tidak terdapat pengaruh yang signifikan $(0,131>0,05)$. Untuk 2 detik dengan 3 detik atau sebaliknya nilai signifikannya 0,015 bahwa terdapat pengaruh yang signifikan $(0,015<0,05)$. Untuk 1 detik dengan 3 detik atau sebaliknya nilai signifikannya 0,002 bahwa terdapat pengaruh yang signifikan $(0,002<0,05)$.

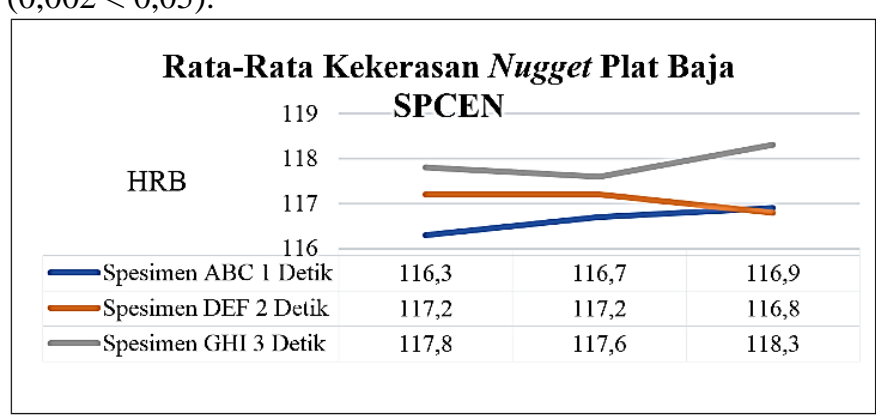

Gambar 4. Grafik Rata-Rata Kekerasan Nugget Plat Baja SPCEN

Gambar grafik 4, data diambil dari tabel II. Hasil rata-rata kekerasan nugget terendah terdapat pada pelat baja $\mathrm{ABC}$ waktu 1 detik dengan rata-rata kekerasan nugget 116,6 HRB dan rata-rata kekerasan nugget tertinggi terdapat pada pelat baja GHI waktu 3 detik dengan rata-rata kekerasan nugget 117,9 HRB. Terlihat garis HRB pada gambar diatas tidak stabil naik turun dengan waktu yang sama dan voltase yang sama yaitu 1,79 volt, memiliki kekerasan nugget yang berbeda dikarenakan pada saat dilakukannya pengelasan titik (spot welding) menghasilkan ampere yang tidak sama besarnya dengan diukur menggunakan alat pengukur clamp meter.

\section{Hasil Data Uji Anova One Way Pengujian Geser Tabel VI Hasil Uji Anova One Way Pengujian Geser ANOVA}

Geser
\begin{tabular}{|l|r|r|r|r|r|}
\hline & Sum of Squares & df & Mean Square & F & Sig. \\
\hline Between Groups & 739551,378 & 2 & 369775,689 & 85,167 &, 000 \\
Within Groups & 26050,690 & 6 & 4341,782 & & \\
Total & 765602,068 & 8 & & & \\
\hline
\end{tabular}

Pada tabel VI dapat disimpulkan bahwa nilai $\mathrm{F}$ hitung lebih besar daripada nilai $\mathrm{F}$ tabel $(85,167>5,14)$ dan nilai signifikan 0,00 kurang dari $0,05(0,00<0,05)$ maka Ha diterima dan Ho ditolak. Dengan kata lain ada pengaruh waktu 
pengelasan titik (spot welding) secara signifikan terhadap kekuatan geser pada plat baja SPCEN.

Tabel VII Hasil Uji LSD Pengujian Geser Multiple Comparisons

Dependent Variable: Geser

LSD

\begin{tabular}{|ll|r|r|r|r|r|}
\hline & & \multirow{2}{*}{$\begin{array}{c}\text { Mean } \\
\text { (I) Waktu }\end{array}$} & & & & \multicolumn{2}{|c|}{$95 \%$ Confidence Interval } \\
\cline { 6 - 8 } & (J) Waktu & Difference (1-J) & Std. Error & Sig. & Lower Bound & Upper Bound \\
\hline & 2 Detik & $-548,63667^{\circ}$ & 53,80075 & .000 & $-680,2824$ & $-416,9910$ \\
& 3 Detik & $-653,82333^{*}$ & 53,80075 &, 000 & $-785,4690$ & $-522,1776$ \\
\hline 2 Detik & 1 Detik & $548,63667^{*}$ & 53,80075 &, 000 & 416,9910 & 680,2824 \\
& 3 Detik & $-105,18667$ & 53,80075 &, 098 & $-236,8324$ & 26,4590 \\
\hline 3 Detik & 1 Detik & $653,82333^{\circ}$ & 53,80075 &, 000 & 522,1776 & 785,4690 \\
& 2 Detik & 105,18667 & 53,80075 &, 098 & $-26,4590$ & 236,8324 \\
\hline
\end{tabular}

${ }^{*}$. The mean difference is significant at the 0.05 level.

Pada tabel VII dapat diketahui 1 detik dengan 2 detik atau sebaliknya nilai signifikannya 0,000 bahwa terdapat pengaruh yang signifikan $(0,000<0,05)$. Untuk 2 detik dengan 3 detik atau sebaliknya nilai signifikannya 0,098 bahwa tidak terdapat pengaruh yang signifikan $(0,098>0,05)$. Untuk 1 detik dengan 3 detik atau sebaliknya nilai signifikannya 0,000 bahwa terdapat pengaruh yang signifikan $(0,000<0,05)$.

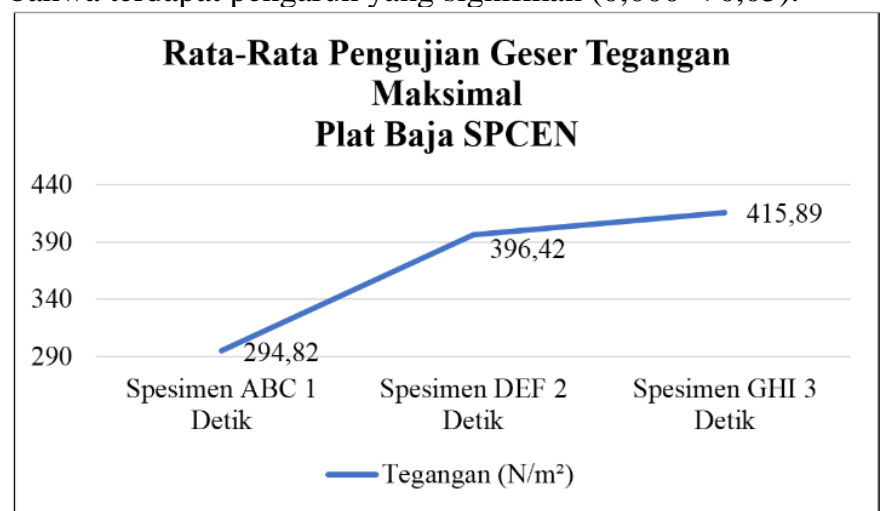

Gambar 6. Grafik Rata-Rata Pengujian Geser Tegangan Maksimal Plat Baja SPCEN

Gambar grafik 6, data diambil dari tabel III. Hasil rata-rata kekuatan geser tegangan maksimal terendah terdapat pada pelat baja $\mathrm{ABC}$ waktu 1 detik dengan rata-rata 294,82 N/m² dan rata-rata kekuatan geser tegangan maksimal tertinggi terdapat pada pelat baja GHI waktu 3 detik dengan rata-rata $415,89 \mathrm{~N} / \mathrm{m}^{2}$.

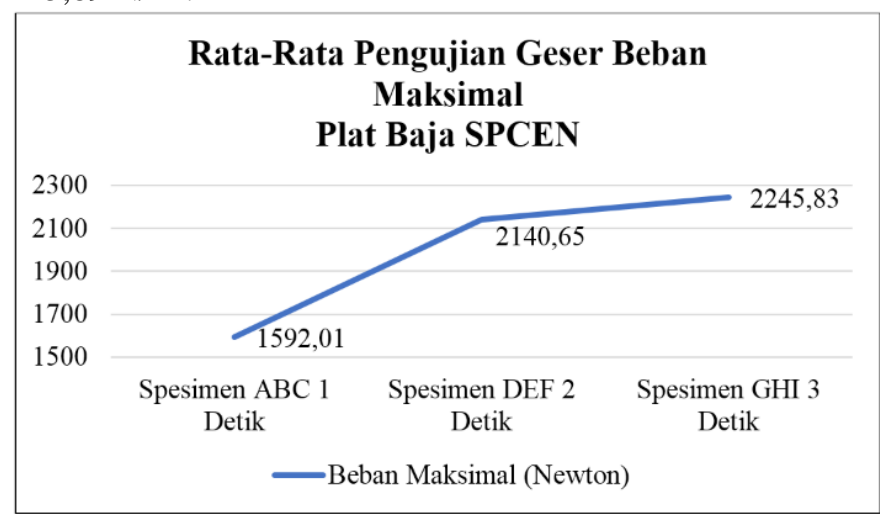

Gambar 7. Grafik Rata-Rata Pengujian Geser Beban Maksimal Plat Baja SPCEN
Gambar grafik 7, data diambil dari tabel III. Hasil ratarata kekuatan geser beban maksimal terendah terdapat pada pelat baja $\mathrm{ABC}$ waktu 1 detik dengan rata-rata 1592,01 Newton. Hasil rata-rata kekuatan geser beban maksimal tertinggi terdapat pada pelat baja GHI waktu 3 detik dengan rata-rata 2245,83 Newton.

\section{Pengaruh Waktu Pengelasan Titik (Spot Welding) Terhadap Kekerasan}

Diketahui dari hasil data pengujian kekerasan tabel II memiliki kekuatan kekerasan rata-rata yang berbeda-beda. Pada tabel IV menunjukan ada pengaruh waktu pengelasan titik (spot welding) secara signifikan terhadap kekerasan pada pelat baja SPCEN. Hal tersebut dapat diketahui dari hasil data menggunakan anova tunggal (anova one way) menggunakan software SPSS yang dijelaskan pada analisa hasil penelitian kekerasan.

Dari hasil data diketahui bahwa hasil rata-rata kekerasan nugget tertinggi terdapat pada pelat baja GHI waktu 3 detik dengan rata-rata kekerasan nugget 117,9 HRB yang artinya full hardness karena sifat kekerasan (Hardness) Rockwell baja SPCEN minimal full hardness 85 HRB. Menjadikan semakin lama waktu pengelasan titik (spot welding) rata-rata kekerasannya meningkat.

Maka semakin besar arus yang digunakan, semakin besar pula panas yang ditimbulkan dan menjadikan kekerasan semakin kuat, padat dan meleburnya lebih baik yang berbanding lurus dengan sambungan lasnya. Ini sesuai dengan persamaan rumus (Amstead B.H, 1995):

$$
\begin{aligned}
\text { Keterangan: } & \mathrm{H}=\mathrm{I}^{2} \cdot \mathrm{R} . \mathrm{t} \\
\mathrm{I} & =\text { Panas }(\text { joule }) \\
\mathrm{R} & =\text { Arus (ampere) } \\
\mathrm{t} & =\text { Waktu (detik) }
\end{aligned}
$$

Dimana arus (I) berbanding lurus dengan panas (H), jika nilai arus (I) besar maka nilai panas $(\mathrm{H})$ juga akan besar.

\section{Pengaruh Waktu Pengelasan Titik (Spot Welding) \\ Terhadap Kekuatan Geser}

Diketahui dari hasil data pengujian geser tabel III memiliki tegangan dan beban maksimal rata-rata yang berbeda-beda. Pada tabel VI menunjukan ada pengaruh waktu pengelasan titik (spot welding) secara signifikan terhadap kekuatan geser pada pelat baja SPCEN. Dari hasil data diketahui bahwa hasil rata-rata kekuatan geser tertinggi terdapat pada pelat baja GHI waktu 3 detik Menjadikan semakin lama waktu pengelasan titik (spot welding) maka semakin besar arus yang digunakan, semakin besar pula panas yang ditimbulkan dan menjadikan sambungan las semakin kuat, padat dan meleburnya lebih baik. Untuk daerah elastis linier, tegangan geser berbanding lurus dengan regangan geser, sesuai dengan persamaan rumus Hukum Hooke (Hooke's Law) $\tau=\frac{F}{A}$

Keterangan: $\tau=$ Tegangan geser $\left(\mathrm{N} / \mathrm{m}^{2}\right)$

$$
\begin{aligned}
& \mathrm{F}=\text { Gaya yang diterapkan (Newton) } \\
& \mathrm{A}=\text { Luas spesimen }\left(\mathrm{m}^{2}\right)
\end{aligned}
$$

Dan sesuai dengan persamaan rumus (Amstead B.H, 1995): 


$$
\begin{aligned}
& \mathrm{H}=\mathrm{I}^{2} \cdot \mathrm{R} . \mathrm{t} \\
\text { Keterangan: } & \mathrm{H}=\text { Panas }(\text { joule }) \\
\mathrm{I} & =\text { Arus }(\text { ampere }) \\
\mathrm{R} & =\text { Resistansi listrik / hambatan }(\text { ohm }) \\
\mathrm{t} & =\text { Waktu (detik) }
\end{aligned}
$$

Dimana arus (I) berbanding lurus dengan panas (H), jika nilai arus (I) besar maka nilai panas $(\mathrm{H})$ juga akan besar.

\section{Pengaruh Waktu Pengelasan Titik (Spot Welding) Terhadap Diameter Nugget}

Diketahui dari hasil data pengujian diameter nugget tabelI memiliki diameter nugget rata-rata yang sama. Bahwa semakin lama waktu pengelasan titik (spot welding) maka semakin besar arus yang digunakan, semakin besar pula panas yang ditimbulkan dan menjadikan hasil las nugget lebih baik Pada saat pengukuran diameter nugget terlihat hasil las yang terjadi semakin kuat, padat dan meleburnya lebih baik, akan tetapi tidak menjadikan diameter nugget semakin besar pula.

\section{KESIMPULAN}

Berdasarkan analisa data pada pengujian kekerasan dan pengujian geser pelat baja SPCEN, didapatkan kesimpulan sebagai berikut:

- Terdapat pengaruh yang signifikan terhadap kekerasan nugget dan kekuatan geser. Semakin lama waktu pengelasan, maka kekerasan nugget yang terjadi menjadi lebih baik dan kekuatan geser semakin besar pula. Semakin lama waktu pengelasan hasil nugget semakin baik dan tidak berpengaruh terhadap besar diameter nugget.

- Waktu yang terbaik pada pengelasan titik (spot welding) untuk kekerasan dan kekuatan geser pada pelat baja SPCEN adalah waktu 3 detik karena dengan hasil kekerasan dan kekuatan geser tertinggi dengan kekerasan nugget 117,9 HRB full hardness.

\section{UCAPAN TERIMA KASIH}

Rasa terima kasih peneliti sampaikan kepada kedua orang tua dan keluarga peneliti skripsi yang telah memberikan doa dan dukungan baik secara moril maupun materi.

\section{REFERENSI}

\section{DAFTAR PUSAKA}

[1] ASTM International. 2001. "Standart Test Method For Apparent Shear Strenght Of Single Lap Joint Adhesively Bonded Metal Specimens". United States: West Conshohocken.

[2] ASTM International. 2004. "Standard Test Methods for Rockwell Hardness and Rockwell Superficial Hardness of Metallic Materials". United States: West Conshohocken.

[3] Deutsche Norm. 1995. "Rockwell Hardness Testing of Metallica Materials Modified Rockwell Scales BM and FM (For Thin Sheet Steel)". German: German Institute for Standardisation.
[4] Drastiawati, Novi Sukma dan Zakiyya, Hanna. 2018. Proses Manufaktur II (Teknik Pengelasan). Surabaya: Universitas Negeri Surabaya.

[5] Muamar Muslih, Nicho. 2012. "Analisa Pengaruh Parameter Pengelasan Spot Welding Terhadap Kekuatan Geser Pada Material Aluminium". Surakarta: Universitas Muhammadiyah Surakarta.

[6] Nugroho, Eko, Dharma, Untung Surya, dan Karuniawan, Sodik. 2018. "Analisis Pengaruh Ketebalan Plat Baja Karbon Rendah Dan Lama Penekanan Pada Pengelasan Titik (Spot Welding) Terhadap Nilai Kekuatan Tarik". Lampung: Universitas Muhammadiyah Metro.

[7] Purwo Raharjo, Wahyu dan Ariawan, Dody. 2005. "Pengaruh Welding Time Terhadap Struktur Mikro Dan Kekerasan, Sambungan Lap Baja Tahan Karat Feritik AISI 430 Dengan Metode Resistance Spot Welding”. Semarang: Universitas Negeri Semarang.

[8] Rinaldo, Edo. 2010. Pengaruh Perubahan Waktu Pengelasan Pada Spot Welding Terhadap Kekuatan Sambungan, Diameter Nugget, Kekerasan Dan Struktur Mikro Pada Baja SPCEN Imm. Surabaya: Institut Teknologi Sepuluh Nopember.

[9] Silaban, Valco, Waskito, dan Purwantono. 2016. "Pengaruh Paramater Pengelasan Spot Welding Terhadap Kekuatan Geser Pada Aluminium". Padang: Universitas Negeri Padang.

[10] Tim Penyusun. 2014. Pedoman Penulisan Skripsi Program Sarjana Strata 1 Universitas Negeri Surabaya. Surabaya: Universitas Negeri Surabaya.

[11] Wicaksono, Qolil. 2015. "Proses Pembuatan Fuel Tank Suzuki Satria FU 150 Pada Section Welding Di PT. Suzuki Indomobil Motor". Depok: Gunadarma University.

[12] Yukichi, Fukuzawa. 2005. "JIS G 3141 : 2005 (JISF) Cold-reduced Carbon Steel Sheets And Strips". Japan: Japanese Standards Association. 